\title{
Micro-endemic populations of Palaeocbeloctonus Lourenço, 1996 (Scorpiones: Hormuridae) in Madagascar: A new case of vicariance among Malagasy scorpions
}

\section{Микроэндемичные попумяџии Palaeocheloctonus Lourenço, 1996 (Scorpiones: Hormuridae) на Мадагаскаре: новый случай викарианса среди мальгашских скорпионов}

\author{
Wilson R. Lourenço ${ }^{1}$, Lucienne Wilmé ${ }^{2}$

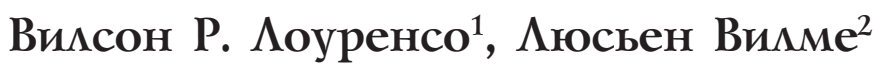

\begin{abstract}
${ }^{1}$ Muséum national d'Histoire naturelle, Département Systématique et Evolution, UMR7205, CP 053, 57 rue Cuvier, 75005 Paris, France. E-mail: arachne@mnhn.fr

${ }^{2}$ Missouri Botanical Garden, Madagascar Research \& Conservation Program, BP 3391, Antananarivo 101, Madagascar. E-mail: lucienne.wilme@mobot-mg.org
\end{abstract}

KEY WORDS: scorpion, new species, Palaeocheloctonus, Hormuridae, micro-endemism, vicariance, Madagascar.

КЛЮЧЕВЫЕ СЛОВА: скорпион, новый вид, Palaeocheloctonus, Hormuridae, микроэндемизм, викарианс, Мадагаскар.

ABSTRACT. A new scorpion species, Palaeocheloctonus septentrionalis sp.n., is described from the North of Madagascar. The new species clearly suggests a new case of micro-endemic and vicariant population within the island. The number of Palaeocheloctonus species in Madagascar is now increased to two and the known geographical distribution of the genus is extended within that great island, but remains strongly disrupted.

РЕЗЮМЕ. С севера Мадагаскара описан новый вид скорпионов: Palaeocheloctonus septentrionalis sp.n. Этот новый вид предполагает еще один случай микроэндемичной и викариантной популяции в пределах острова. Число видов Palaeocheloctonus теперь достигло двух, а хотя географическое распространение рода на этом огромном острове и расширилось, но остается сильно разорванным.

\section{Introduction}

As outlined in recent papers [Lourenço, 2014a, b], Madagascar is one of the most biologically diverse regions on Earth and presents a significant number of micro-endemic populations [Lourenço, 2014a]. One of the first regions to be characterized as presenting a high level of micro-endemic populations was 'Cap Sainte Marie' in the extreme South of the island [Lourenço, 1996, 2014a].

Over a period of more than 20 years a continuous exploration of most habitats in Madagascar has made it possible to examine in a new light the patterns of geographical distribution, taxonomy, diversity, and endemicity of Malagasy scorpions. It can be estimated that from 1995 to 2014, the number of recognized scorpion taxa on Madagascar has risen by more than 400\% [Lourenço, 1996, 2003, 2014a, b].

Besides the South and Southwestern regions of Madagascar, other areas have proven to show particularly high levels of scorpion diversity and endemism, such as the extreme North of the Island. Up to now, a considerable number of endemics have also been described from the region of the 'Montagne des Français' in the extreme North of the island [Lourenço, 2014b; Lourenço, Goodman, 2006; Lourenço et al., 2006]. This was presumably correlated with a combination of unique habitats and a complex geological history with numerous cases of vicariant events associated with paleoclimate oscillations, refugia, and volcanism [Brenon, 1972; Wilmé et al., 2006].

The present study of some further specimens of hormurid scorpions belonging to the genus Palaeocheloctonus Lourenço, 1996, has resulted in the discovery of one new species. The type material has been collected from the 'Montagne des Français' in the extreme North of Madagascar, and is related to the only other known, and type, species of this genus, $P$. pauliani Lourenço, 1996, which has a range of distribution limited to the region of Toliara in Southwestern Madagascar. This new case of disrupted distribution clearly illustrates one more example of micro-endemism and vicariance among the populations of Malagasy scorpions. 

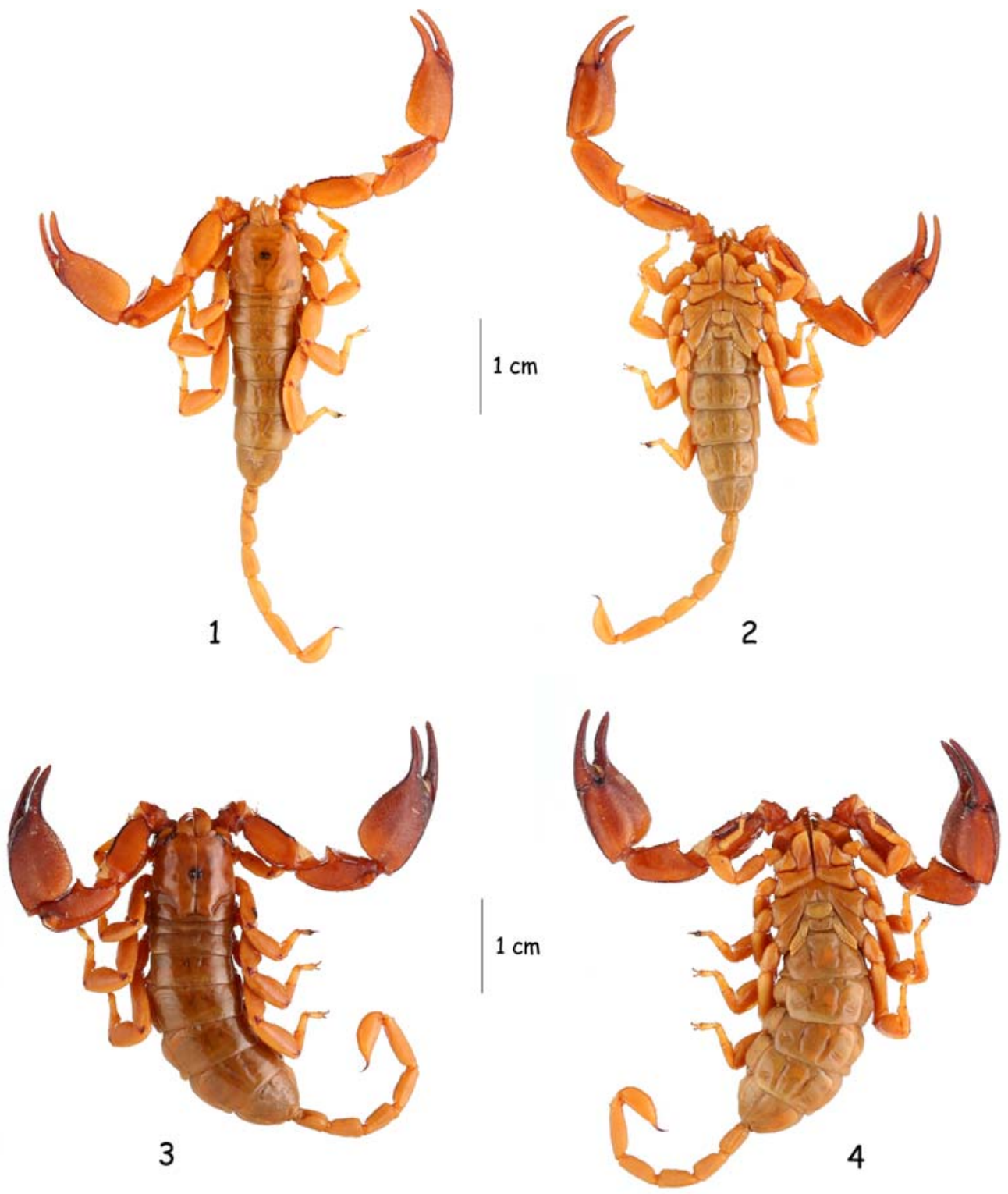

Figs 1-4. Palaeocheloctonus septentrionalis sp.n., $\sigma^{\top}$ holotype $(1,2)$ and + paratype $(3,4)$, dorsal and ventral aspects, respectively. Pис. 1-4. Palaeocheloctonus septentrionalis sp.n., голотип $\sigma^{7}(1,2)$ и паратип $+(3,4)$, соответственно сверху и снизу.

\section{Material and methods}

The holotype is deposited in the Muséum National d'Histoire Naturelle, Paris. One paratype is deposited in the Zoological Museum, State University of Moscow, Russia (ZMUM). Scorpions were collected during day-light and found under rocks. Illustrations and measurements were made with the aid of a Wild M5 stereo-microscope equipped with a drawing tube (camera lucida) and an ocular micrometer. Measurements follow Stahnke [1970] and are given in mm. Trichobothrial notations follow Vachon [1974] and morphological terminology mostly follows Vachon [1952] and Hjelle [1990].

\section{Taxonomic part}

Family Hormuridae Laurie, 1896

Genus Palaeocheloctonus Lourenço, 1996

Palaeocheloctonus septentrionalis sp.n. Figs 1-14, 16, 18.

HOLOTYPE $\sigma^{\top}$ (MNHN), Madagascar, DIANA Region, Montagne des Français, Madagascar western dry forest/wooded grassland-bushland, anthropic grasslands, under rocks, IX.2001, leg. W. R. Lourenço. PARATYPE: 1 (ZMUM Tb-550), same data as for holotype. Scorpions collected during day-light.

NAME. The specific name refers to the northern distribution of the species in the island. 

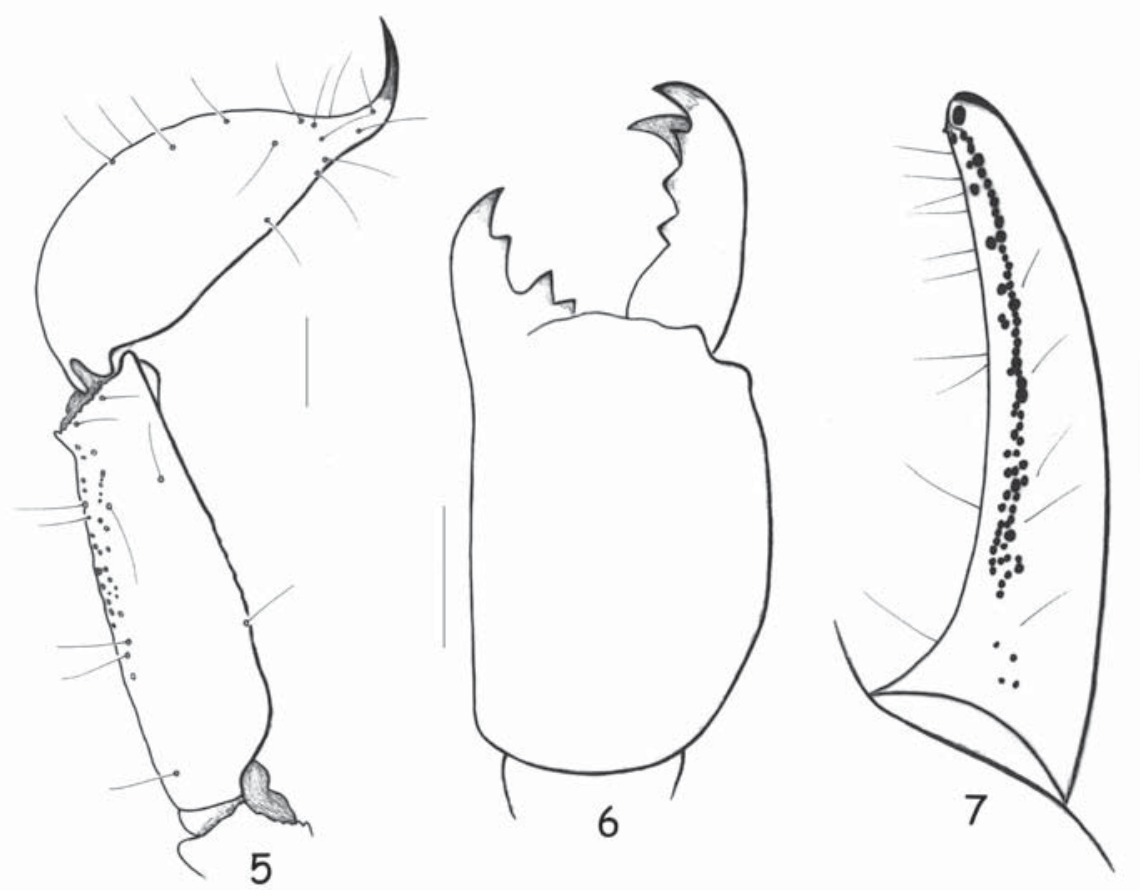

Figs 5-7. Palaeocheloctonus septentrionalis sp.n., $\mathrm{O}^{7}$ holotype. 5 - metasomal segment $\mathrm{V}$ and telson, lateral aspect; 6 - chelicera, dorsal aspect; 7 - cutting edge of movable chelal finger with rows of granules. Scale bar: $1 \mathrm{~mm}$.

Рис. 5-7. Palaeocheloctonus septentrionalis sp.n., голотип О’. 5 - сегмент V метасомы и тельсон, сбоку; 6 - хелицера, сверху; 7 - режущий край подвижного пальца хелы с рядами гранул. Масштаб 1 мм.

DIAGNOSIS. Medium-size scorpions: $O^{7}$ and $o$ 56.4 and $62.9 \mathrm{~mm}$ in total length, respectively. Coloration from pale yellow to reddish yellow; $\sigma^{7}$ without any dark to blackish zones on pedipalp carinae and chelal fingers (Figs 1-2). Pectines with 6-6 and 6-7 teeth in $0^{7}$ and + , respectively. Hemispermatophore with distal lamina more enlarged than in P. pauliani (Figs 17-18). $\sigma^{\top}$ genital operculum large and slightly oval in shape. $P$ genital operculum a slightly cordiform plate without any incision at base (Figs 15-16). Trichobothrial pattern of type C, orthobothriotaxy (Figs 8-14).

RELATIONSHIPS. The new species can be distinguished from $P$. pauliani by a number of characters: (i) distinct morphometric values, (ii) a paler coloration with the absence in the $\sigma^{7}$ of any dark or blackish spots on pedipalp carinae and chela fingers, (iii) granulations on metasomal segments and tergite VII slightly better marked, (iv) $P$ without any incision at base of genital operculum plate. Moreover, both species show a totally disrupted distribution $(>1,300 \mathrm{~km})$ and appear to be vicariant elements.

DESCRIPTION. Based on the $\sigma^{7}$ holotype and the o paratype. Morphometric measurements are listed after the description.

Coloration. Basically pale yellow to reddish yellow; $\sigma^{7}$ without any dark zones on body and appendages. Carapace yellow; median and lateral eyes surrounded by black pigment. Tergites yellow to pale yellow without spots. Metasomal segments yellow, without any spot; vesicle pale yellow; aculeus dark reddish.
Chelicerae yellow; entire surface without any variegated spots; fingers yellow with reddish teeth. Pedipalps reddish yellow; carinae slightly darker in $\uparrow$. Venter and sternites yellow to pale yellow; pectines and genital operculum paler than sternum and coxapophysis; legs yellow.

Morphology. Carapace without granulations, but with punctation; smooth; furrows shallow. Anterior margin with a strong concavity reaching as far as level of 2 nd lateral eye. Median ocular tubercle flattened, located in the centre of carapace; median eyes moderate, separated by one ocular diameter; three pairs of large lateral eyes. Sternum pentagonal, slightly longer than wide. $\bigcirc^{7}$ genital operculum large and slightly oval in shape. + genital operculum a slightly cordiform plate without any incision at base. Tergites with only a vestigial median carina, smooth and with punctations; VII with minute granulation. Pectinal tooth count 6-6 in holotype and 6-7 in paratype. Sternites smooth and shining; VII acarinate with a few punctations. Metasomal segments I to V longer than wide, with some thin granulations. All carinae weakly marked in segments I-IV; segment V rounded with some minute spinoid granules on ventral surface. All segments with moderate chaetotaxy. Telson pear-like in shape; smooth and covered with moderate to strong chaetotaxy. Pedipalps: femur with dorsal internal, dorsal external, ventral internal and ventral external carinae strong, tuberculate; dorsal face with very thin granulation; ventral face with a few granulations; internal face moderately granulat- 

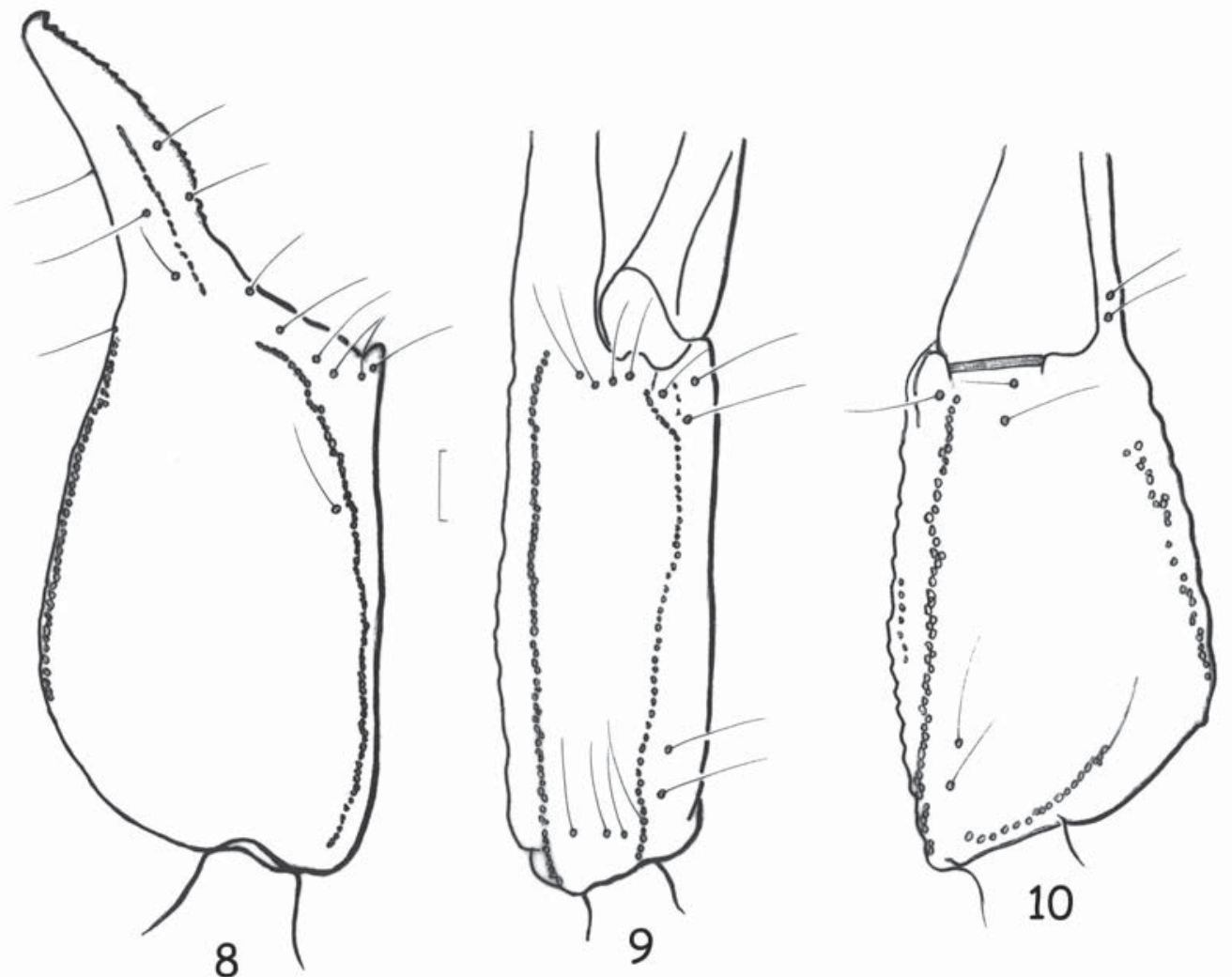

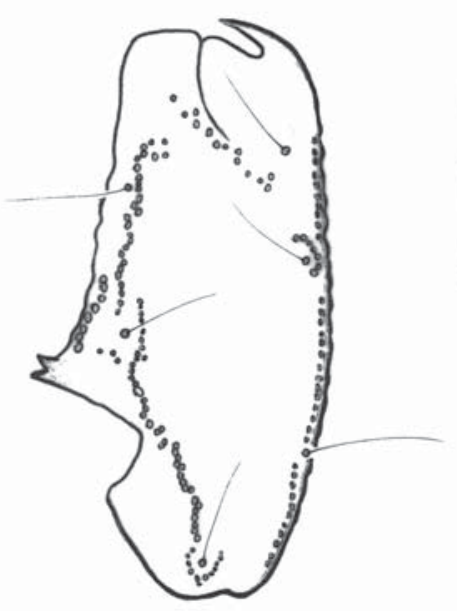

11

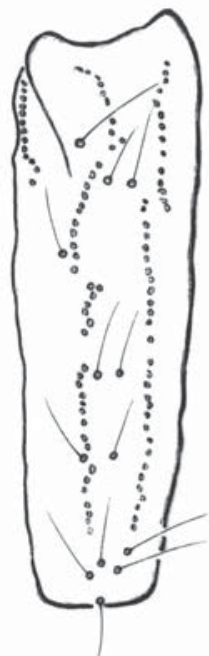

12

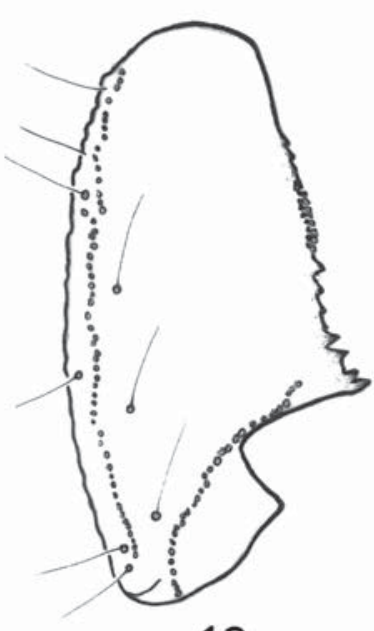

13

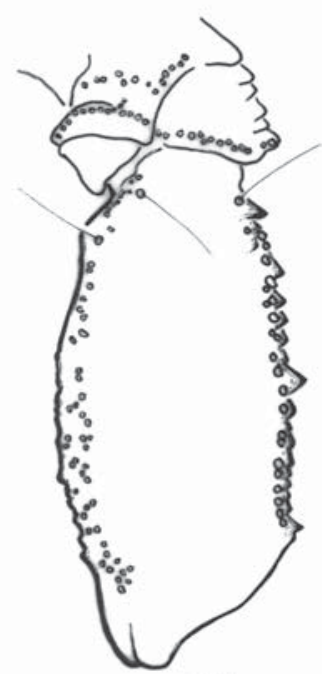

14

Figs 8-14. Palaeocheloctonus septentrionalis sp.n., $\sigma^{7}$ holotype, trichobothrial pattern. 8-10 - chela, dorso-external, external and ventral aspects, respectively; 11-13 — patella, dorsal, external and ventral aspects, respectively; 14 - femur, dorsal aspect. Scale bars: 1 mm.

Рис. 8-14. Palaeocheloctonus septentrionalis sp.n., голотип О', характер размещения трихоботрий. 8-10 - хела, соответственно одновременно сверху и снаружи, снаружи и снизу; 11-13 - пателла, соответственно сверху, снаружи и снизу; 14 - бедро, сверху. Масштаб 1 мм.

ed; external face more strongly granular. Patella with internal and external faces moderately granulated; dorsal and ventral faces smooth and lustrous; dorsal internal, ventral internal, ventral external and external carinae strong; other carinae less well marked. Chela mod- erately to strongly granular including on internal face; dorsal marginal, external secondary, ventro-internal and ventral median carina strong; other carinae less well marked. Dentate margins on movable and fixed fingers with a median row of granules composed of 5-6 groups 


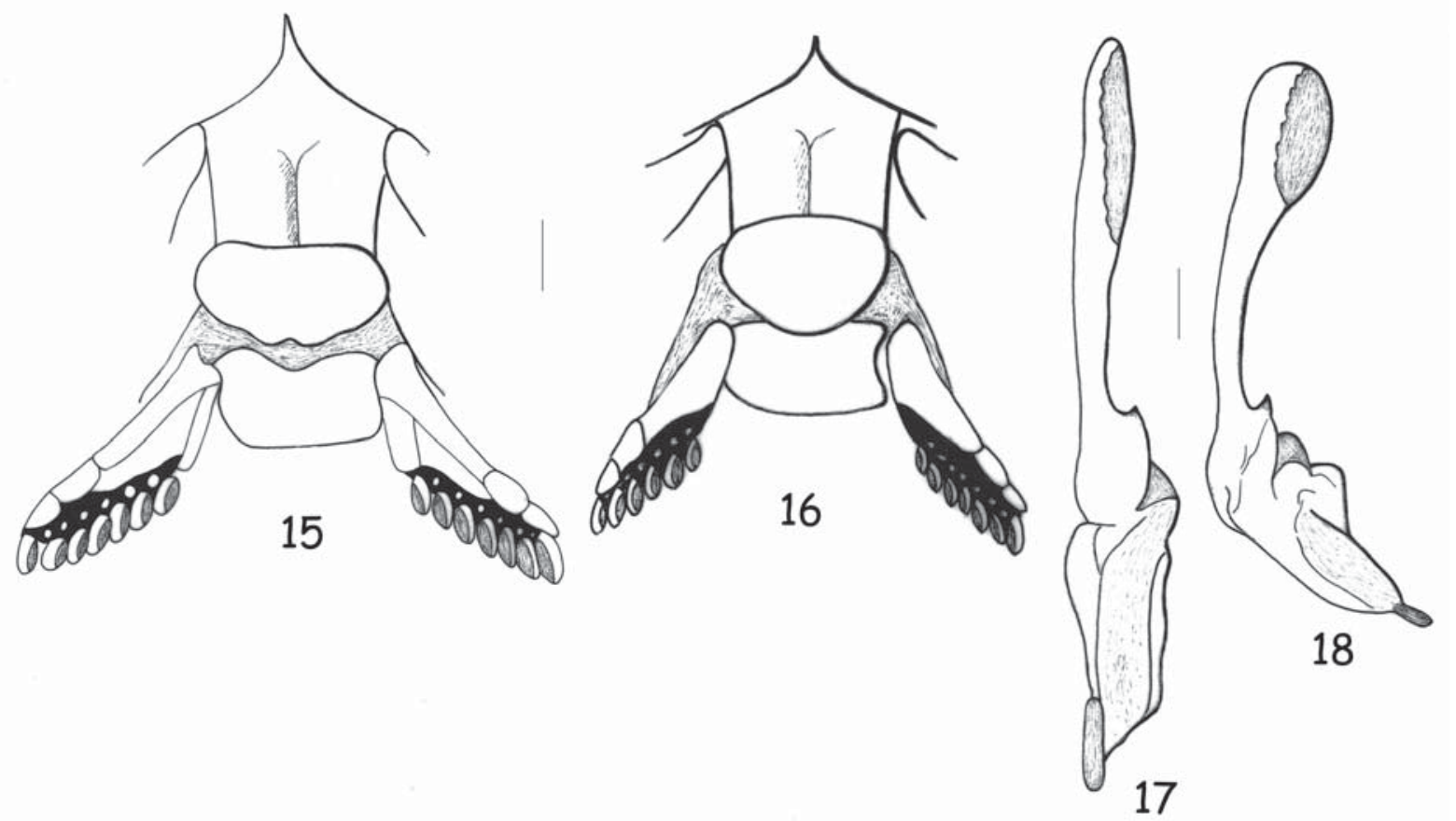

Figs 15-18. Palaeocheloctonus pauliani Lourenço, $1996(15,17)$ and $P$. septentrionalis sp.n. $(16,18), \sigma^{\top}$ holotypes and $\bigcirc$ paratypes. 15-16 - ventral aspect, showing sternum, the shape of the genital operculum plates and pectines; $17-18-$ hemispermatophore, external aspect. Scale bars: $1 \mathrm{~mm}$.

Рис. 15-18. Palaeocheloctonus pauliani Lourenço, $1996(15,17)$ и P. septentrionalis sp.n. $(16,18)$, голотипы $\sigma^{7} \sigma^{7}$ и паратипы фо. 15-16 - вид снизу, показывающий стернит, форму пластин генитальной крышечки и пектины; 17-18 - гемисперматофор, снаружи. Масштаб 1 мм.

of small sub-granules separated by larger accessory granules. Chelicerae typical of Scorpionoidea [Vachon, 1963]; teeth sharp. Trichobothriotaxy type C; orthobothriotaxic [Vachon, 1974]. Legs: tarsi with two lateral rows of spines, surrounded by a few long setae. Spurs moderate. Hemispermatophore as in Fig. 18, with distal lamina short and moderately enlarged.

Morphometric values (in $\mathrm{mm}$ ) of holotype and paratype of $P$. pauliani and $P$. septentrionalis sp.n. Total length (including telson) 48.8/52.8/56.4/62.9. Carapace: length 7.4/8.1/8.2/9.7; anterior width 4.9/ 5.2/5.3/6.4; posterior width 7.6/8.6/8.0/9.4. Mesosoma length 19.1/21.3/24.4/24.9. Metasomal segment I: length $2.4 / 2.4 / 2.7 / 3.2$, width $1.8 / 1.9 / 1.8 / 2.2$; II: length $2.8 /$ $3.2 / 3.1 / 3.6$, width $1.6 / 1.7 / 1.6 / 1.9$; III: length $3.1 / 3.2 /$ $3.2 / 4.1$, width $1.5 / 1.6 / 1.6 / 1.7$; IV: length $3.7 / 3.8 / 3.8 /$ 4.4, width $1.4 / 1.6 / 1.5 / 1.6$; V: length $4.8 / 5.2 / 5.2 / 6.2$, width $1.4 / 1.5 / 1.5 / 1.6$, depth 1.6/1.6/1.8/1.9. Telson length 5.5/5.6/5.8/6.8. Vesicle: width $1.7 / 1.6 / 1.8 / 1.8$, depth 1.8/1.9/2.1/2.3. Pedipalp: femur length $6.9 / 6.6 /$ 7.5/7.6, width $3.0 / 3.2 / 3.5 / 3.8$; patella length $7.8 / 7.5 /$ $8.3 / 8.6$, width $3.5 / 3.6 / 3.8 / 4.2$; chela length $12.8 / 13.3 /$ $13.8 / 15.8$, width $4.4 / 4.7 / 4.6 / 6.2$, depth 5.3/6.0/5.6/7.2; movable finger length $6.2 / 6.6 / 6.6 / 8.2$.

\section{Biogeographic comments}

In some recent papers, Lourenço [2013, 2014a, b] outlined that the global patterns of distribution ob- served for a given zoological group have largely been driven by historical factors which took place in more or less recent periods of time. Recent times, e.g., the Pleistocene and Holocene epochs, were characterized by paleoclimate oscillations, variable in time and space, with alternating warm and cold periods at higher latitudes, and wet and dry periods at lower latitudes. For instance, during the Last Glacial Maximum, ca. 20,000 my BP, more water was stored as ice, the sea-level was lower, and there was less water in circulation. During these dry periods, forests receded, together with forestdwelling fauna and flora, except in some refugia where forests persisted [Mercier, Wilmé, 2013]. This historical reduction of rainforests to patch refugia is supported by the existing biogeographical patterns of distribution and differentiation of several taxa, as well as by palynological and geomorphological evidence from many regions of the world. A number of authors also postulate that the reduction of forest to small patches stimulated many changes in plant and animal populations in the refugia. These ranged from extinction to an increased rate of speciation [Van der Hammen, 1974, 1982; Prance 1982a, b; Bennet, Provan, 2008]. In the case of Madagascar, however, as stated by Burney [1996, 1997] these theories have received less attention than elsewhere. For further details on these processes the readers may refer to Lourenço [2014b].

As already suggested for the species belonging to the genus Opisthacanthus [Lourenço, 2014b], the dis- 


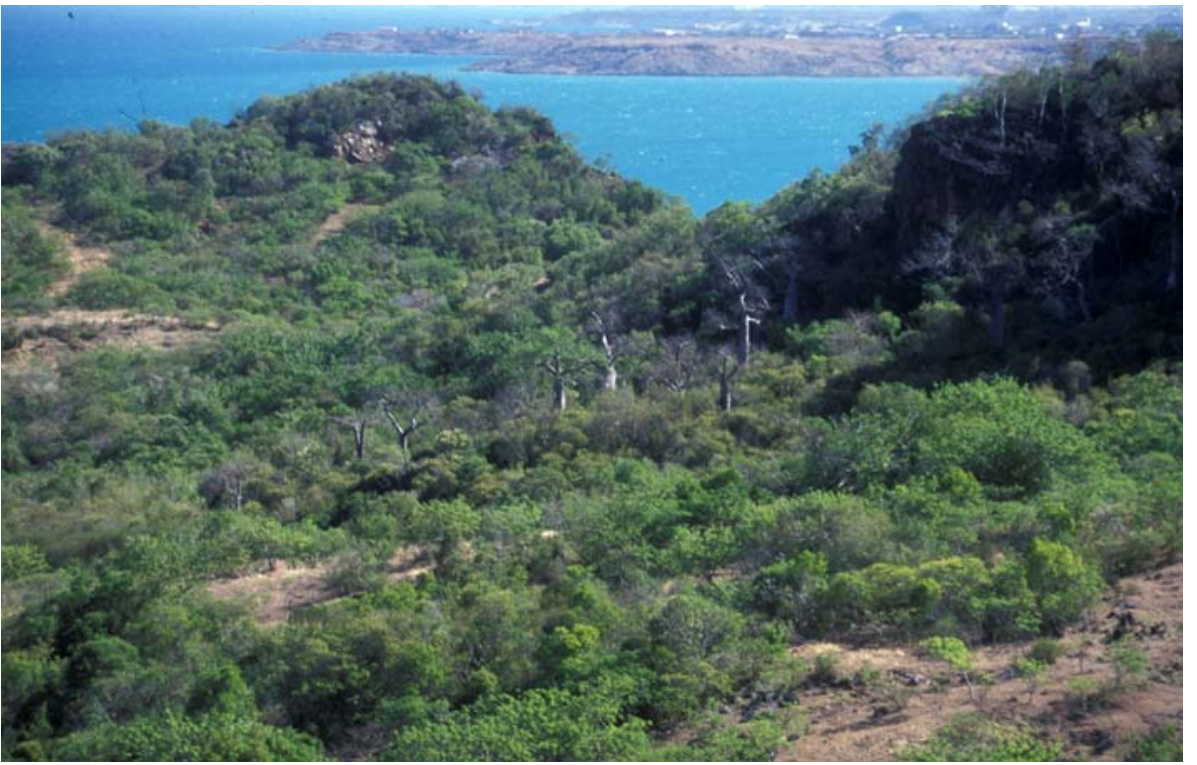

Fig. 19. The typical vegetation of the Montagne des Français region, type locality of Palaeocheloctonus septentrionalis sp.n.

Рис. 19. Типичная растительность района Montagne des Franзаis, типовой местности для Palaeocheloctonus septentrionalis sp.n.

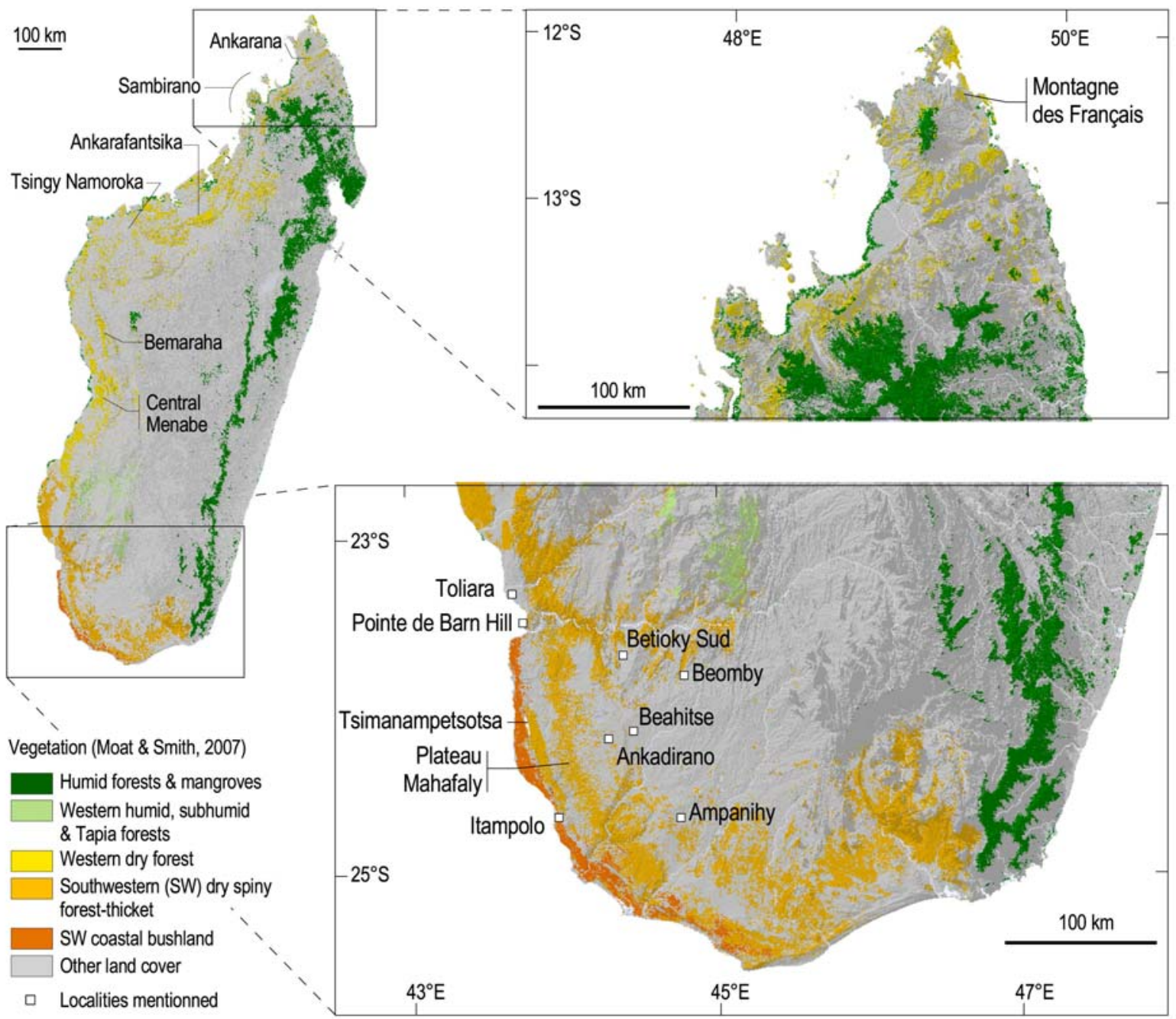

Fig. 20. Map of Madagascar with the known collection sites of Palaeocheloctonus pauliani Lourenço, 1996, in the south (bottom right) and of $P$. septentrionalis sp.n. in the north (top right).

Рис. 20. Карта Мадагаскара с известными местами сборов Palaeocheloctonus pauliani Lourenço, 1996, на юге (внизу справа) и P. septentrionalis sp.n. на севере (наверху справа). 
tribution pattern observed for the two known species of Palaeocheloctonus, P. pauliani and P. septentrionalis sp.n., confined to the arid formations of Southwestern and extreme North regions of the island, respectively (Fig. 20), can tentatively be explained as the result of a past continuous distribution over arid formations which might have changed subsequently during recent Quaternary vicissitudes in a vicariant process [Bernardi, 1986]. Some dry forest areas lying above similar sedimentary formations in western Madagascar, as the one encountered at Montagne des Français, have been identified as centres of endemism for mammals and birds [Wilmé et al., 2012]. Amongst these areas, some have been intensely inventoried, including the central Menabe, the tsingys of Bemaraha or Namoroka, Ankarafantsika, or Ankarana, amongst others, but have not yielded any Palaeocheloctonus. On another hand, only the region towards the extreme North of the island shows arid conditions similar to the ones encountered in Southwestern Madagascar [Cornet, 1974; Moat, Smith, 2007], but recent bioclimates are certainly not explaining the entire 'story' and the Madagascar scorpions still have many secrets to reveal. The Northern band of humid forests is spanning from the Northeast coast to the Northwest into the Sambirano region (Fig. 20) where these humid and subhumid forests may have acted as a barrier for the dispersal of Palaeocheloctonus, once the monsoon system prevailed in Northern Madagascar during the late Miocene or early Pliocene [Wells, 2003].

ACKNOWLEDGEMENTS. We are most grateful to Elise-Anne Leguin (MNHN) for her assistance with the preparation of the photos and plates, to Kathrin Glaw (Germany) for the permission to use the picture of the 'Montagne des Français', and to Sergei Golovatch, Russian Academy of Sciences, Moscow, for his interest in the publication of this article.

\section{References}

Bennett K.D., Provan J. 2008. What do we mean by 'refugia'? // Quaternary Science Reviews. Vol.27. P.2449-2455.

Bernardi G. 1986. La vicariance, la pseudovicariance et la convergence allopatrique // Bulletin d'Ecologie. T.17. Fasc.3. P.145154.

Brenon P. 1972. The geology of Madagascar // Battistini R., Richard-Vindard G. (eds.). Biogeography and Ecology in Madagascar. The Hague: W. Junk. P.27-86.

Burney D.A. 1996. Climate change and fire ecology as factors in the quaternary biogeography of Madagascar // Lourenço W.R. (ed.). Biogéographie de Madagascar. Paris: Edition de l'ORSTOM. P.49-58.

Burney D.A. 1997. Theories and facts regarding Holocene environmental change before and after human colonization // Goodman S.M., Patterson B.D. (eds.). Natural Change and Human Impact in Madagascar. Washington: Smithsonian Institution Press. P.75-89.

Cornet A. 1974. Essai de cartographie bioclimatique à Madagascar. Notice explicative $\mathrm{n}^{\circ}$ 55. Paris: ORSTOM. 28 pp.

Hjelle J.T. 1990. Anatomy and morphology // Polis G.A. (ed.). The Biology of Scorpions. Stanford: Stanford Univ. Press. P.9-63.
Lourenço W.R. 1996. Scorpions (Chelicerata, Scorpiones) // Faune de Madagascar. Paris: Muséum national d'Histoire naturelle. No.87. $102 \mathrm{pp}$.

Lourenço W.R. 2003. Scorpions // Goodman S.M., Benstead J.P (eds.). Natural History of Madagascar. The University of Chicago Press: Chicago. P.575-579.

Lourenço W.R. 2013. A new species of Grosphus Simon, 1880 (Scorpiones, Buthidae) from Central Madagascar // Entomologische Mitteilungen aus dem Zoologischen Museum Hamburg. Bd.16. H.189. P.57-62.

Lourenço W.R. 2014a. The genus Grosphus Simon, 1880 from south-western Madagascar, with the description of a new species (Scorpiones, Buthidae) // Zoosystema. Vol.36. No.3. P.631645.

Lourenço W.R. 2014b. Micro-endemic and vicariant populations of Opisthacanthus Peters, 1861 (Scorpiones: Hormuridae) in Madagascar, with the descriptions of two new species // Arthropoda Selecta. Vol.23. No.4. P.383-391.

Lourenço W.R., Goodman S.M. 2006. Description of a new species of Heteroscorpion Birula, 1903 (Scorpiones, Heteroscorpionidae) from the Montagne des Français in extreme northern Madagascar // Zootaxa. Vol.1269. P.31-41.

Lourenço W.R., Goodman S.M., Fisher B.L. 2006. A reappraisal of the geographical distribution of the endemic family Microcharmidae Lourenço (Scorpiones) in Madagascar and description of eight new species and subspecies // Proceedings of the California Academy of Sciences, $4^{\text {th }}$ Ser. Vol.57. No.26. P.751783.

Mercier J.-L., Wilmé L. 2013. The Eco-Geo-Clim model: explaining Madagascar's endemism // Madagascar Conservation \& Development. Vol.8. No.2. P.63-68.

Moat J., Smith P. 2007. Atlas of the vegetation of Madagascar. Atlas de la végétation de Madagascar. Kew: Kew Publishing, Royal Botanic Gardens. 124 pp.

Prance G.T. (ed.) 1982a. Biological Diversification in the Tropics. New York: Columbia University Press. 714 pp.

Prance G.T. 1982b. Forest refuges: Evidence from woody angiosperms // Prance G.T. (ed.). Biological Diversification in the Tropics. Columbia Univ. Press: New York. P.137-158.

Stahnke H.L. 1970. Scorpion nomenclature and mensuration // Entomological News. Vol.81. P.297-316.

Vachon M. 1952. Etudes sur les scorpions // Publications de l'Institut Pasteur d'Algérie: Alger. 482 p.

Vachon M. 1963. De l'utilité, en systématique, d'une nomenclature des dents des chélicères chez les Scorpions // Bulletin du Muséum national d'Histoire naturelle, Paris. 2ème sér. T.35. P.161-166

Vachon M. 1974. Etude des caractères utilisés pour classer les familles et les genres de Scorpions (Arachnides). 1. La trichobothriotaxie en arachnologie. Sigles trichobothriaux et types de trichobothriotaxie chez les Scorpions // Bulletin du Muséum national d'Histoire naturelle, Paris. 3ème sér. T.140. P.857958.

Van der Hammen T. 1974. The Pleistocene changes of vegetation and climate in tropical South America // Journal of Biogeography. Vol.1. P.3-26.

Van der Hammen T. 1982. Paleoecology of tropical South America // Prance G.T. (ed.). Biological Diversification in the Tropics. Columbia University Press: New York. P.60-66.

Wells N.A. 2003. Some hypotheses on the Mesozoic and Cenozoic paleoenvironmental history of Madagascar // Goodman S.M., Benstead J.P. (eds.). The Natural History of Madagascar. The University of Chicago Press: Chicago. P.16-34.

Wilmé L., Goodman S.M., Ganzhorn J.U. 2006. Biogeographic evolution of Madagascar's microendemic biota // Science. Vol.312. P.1063-1065.

Wilmé L., Ravokatra M., Dolch R., Schuurman D., Mathieu E., Schuetz H., Waeber P.O. 2012. Toponyms for centers of endemism in Madagascar // Madagascar Conservation \& Development. Vol.7. No.1. P.30-40.

Responsible editor S.I. Golovatch 